\title{
Review about the Factors Effect on Asian Swamp Eel (Monopterus Albus)
}

\author{
Ayah Rebhi Hilles ${ }^{1 *}$, Syed Mahmood ${ }^{2}$ and Ridzwan Hashim ${ }^{1}$ \\ ${ }^{1}$ Department of Biomedical Sciences, Kulliyyah of Allied Health Sciences, International Islamic University Malaysia, Malaysia \\ ${ }^{2}$ Department of Pharmaceutical Engineering, Faculty of Engineering Technology, University Malaysia Pahang, Malaysia
}

Submission: April 23, 2018; Published: June 13, 2018

*Corresponding author: Ayah Rebhi Hilles, Department of Biomedical Sciences, Kulliyyah of Allied Health Sciences, International Islamic University Malaysia, Malaysia, Email: yah.hilles90@gmail.com

Syed Mahmood, Department of Pharmaceutical Engineering, Faculty of Engineering Technology, University Malaysia Pahang, 26300 Gambang, Pahang, Malaysia, Email: syedmahmood@ump.edu.my

\section{Introduction}

There are many factors might influence the life and the growth of Asian swamp eel (Monopterus albus), however, $M$. albus can adapt with tough environmental conditions more than other fishes [1]. It usually burrows deep inside the mud during prolonged deficiency of water [2]. It can also move over dry land for short distances [3].

\section{Factors effect on Asian swamp eel (Monopterus albus)}

Effect of salt on M. albus: It has been reported that M. albus can grow in low saline water [4], it has been recorded that $M$. albus survive in brackish water up to $16 \mathrm{gL}^{-1}$ for many weeks [5]. However, exposing M. albus to $25 \%$ salty water for 4 days led to significant elevation in glutamine protein abundance in their liver and muscle [6].

Effect of endosulfan on M. albus: Monopterus albus habitat in rice fields, which make it exposed to toxic pesticides used in the rice fields, especially endosulfan, because it is the most commonly insecticides. It has been proven that endosulfan caused mortality of the eel was after 72 hours of exposure concentration of $1.00 \mu \mathrm{gL}^{-1}$ [7]. Endosulfan is an organochlorine insecticide has been classified as Class IB and Class II pesticides from World Health Organisation (WHO) and the United States Environmental Protection Agency (USEPA) due to its toxic behaviour [8]. Endosulfan consider as persistent organic pollutant with 3 to 7 days half-life in the water and it can also last up to 5 months [9]. Although endosulfan has been banned in many European countries and some Asian countries, but unfortunately it is still widely used in the rice fields in most of the developing countries due to its effectiveness and low application price [10]. Endosulfan is highly toxic to the swamp eels, its toxicity depends on the concentrations and exposure times $[11,12]$.

Effect of Gnathostoma infection on Asian swamp eel: Gnathostoma spinigerum is the major causative agent of human gnathostomiasis [13]. The route of infection is ingestion of uncooked larvae in the fresh water eel [14]. Asian Swamp Eel infection was the greatest among all infected animal species mainly in Thailand, high numbers of Gnathostoma larvae found in the infected swamp eel, the distributions of Gnathostoma larvae was $57.0 \%$ in the liver and $43.0 \%$ in the muscles [15]. It has been reported that Gnathostoma infection in swamp eels was the highest during the rainy season [16]. Intensity of Gnathostoma spinigerum Infective Larvae in Thailand can affect the standard farming of the culture of eels and the risk of consuming undercooked eels [17]. Imported Asian swamp live eels are a potential source of human gnathostomiasis in the United States, the distribution of the infection was $58.3 \%$ in the liver, $19.4 \%$ in the muscle, $13.8 \%$ in gastrointestinal tract, and $8.3 \%$ in the kidneys [18].

Effect of rotenone on Asian swamp eel: Rotenone used for the assessment and management of fishes to eradicate the unwanted introduced species and control their numbers [19]. Rotenone consider a lethal chemical to a wide range of species [20]. It has been used to remove unwanted non-native fishes [21]. It has been reported in Florida that $100 \%$ mortality of adult swamp eels was achieved only at $8 \mathrm{mg} / \mathrm{L}$ which conduct the effectiveness of rotenone as management tool against eel as well as many other aquatic organisms in the treated area [22]. Despite the successes in killing Asian swamp eel, the chemical remains controversial largely because of its broad toxicity and the potential for massive kills of non-targeted animals [23].

Effect of ammonia on Asian swamp eel: The toxicity of ammonia occurs because of the limitation factors in eel farm design and management [24], as is the main nitrogenous excretory product of eel [25]. Sometimes there is no proper water flow and small space giving in the eel tanks due to economic considerations lead to high concentrations of ammonia which may inhibit their growth [26] or cause mortalities [27]. It has been found that the lethal threshold concentration of unionised ammonia for both elvers and glass eels is $1 \mathrm{mg}-\mathrm{N}^{-1}$ [28].

\section{References}

1. Starnes WC, Bryant RT, Greer GC (1998) Perilous experiment: the Asian rice eel in Georgia. Georgia. Natural Georgia Series 7: 60-70. 
2. Liem KF, Inger RF (1987) Functional design of the air ventilation apparatus and overland excursions of Teleosts. Fieldiana Zoology, USA.

3. Tay AS, Chew SF, Ip YK (2003) The swamp eel Monopterus albus reduces endogenous ammonia production and detoxifies ammonia to glutamine during 144h of aerial exposure. J Exp Biol 206(14): 24732486.

4. Pedersen PB, Hansen K, Houng DT, Bayley M, Wang T (2014) Effects of salinity on osmoregulation, growth and survival in Asian swamp eel (Monopterus albus) (Zuiew 1793). Aquaculture Research 45(3): 427438.

5. Schofield PJ, Nico LG (2009) Salinity tolerance of non-native Asian swamp eels (Teleostei: Synbranchidae) in Florida, USA: comparison of three populations and implications for dispersal. Environmental Biology of Fishes 85(1): 51-59.

6. Tok CY, Chew SF, Peh WY, Loong AM, Wong WP, et al. (2009) Glutamine accumulation and up-regulation of glutamine synthetase activity in the swamp eel, Monopterus albus (Zuiew), exposed to brackish water. J Exp Biol 212(9): 1248-1258.

7. Hii YS, Lee MY, Chuah TS (2007) Acute toxicity of organochlorine insecticide endosulfan and its effect on behaviour and some hematological parameters of Asian swamp eel (Monopterus albus, Zuiew). Pesticide Biochemistry and Physiology 89(1): 46-53.

8. Johnson WW, Finley MT (1980) Handbook of acute toxicity of chemicals to fish and aquatic invertebrates: Summaries of toxicity tests conducted at Columbia National Fisheries Research Laboratory, 196578 (No. 137). US Fish and Wildlife Service.

9. Howard PH (1991) Handbook of environmental fate and exposure data: for organic chemicals, volume III pesticides CRC press (3), p. 712.

10. Shanahan M (2003) End of the road for endosulfan: A call for action against a dangerous pesticide. Environmental Justice Foundation.

11. Sunderam RI, Thompson GB, Cheng DM (1992) Toxicity of endosulfan to native and introduced fish in Australia. Environmental Toxicology and Chemistry 11(10): 1469-1476.

12. Capkin E, Altinok I, Karahan S (2006) Water quality and fish size affect toxicity of endosulfan, an organochlorine pesticide, to rainbow trout. Chemosphere 64(10): 793-1800.

13. Kamiya H, Kamiya M, Ohbayashi M, Klongkamnuankarn KO, Vajrasthira SU (1987) Gnathostoma malaysiae Miyazaki and Dunn, 1965 from Rattus surifer in Thailand. Southeast Asian J Trop Med Public Health 18(1): 121-126.

14. Saksirisampant W, Kulkaew K, Nuchprayoon S, Yentakham S, Wiwanitkit $V$ (2002) A survey of the infective larvae of Gnathostoma spinigerum in swamp eels bought in a local market in Bangkok, Thailand. Ann Trop Med Parasitol 96(2): 191-195.

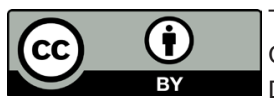

This work is licensed under Creative

Commons Attribution 4.0 License

DOI: 10.19080/CTBEB.2018.15.555915
15. Rojekittikhun W, Chaiyasith T, Nuamtanong S, Komalamisra C (2004) Gnathostoma infection in fish caught for local consumption in Nakhon Nayok Province, Thailand I. Prevalence and fish species. Southeast Asian J Trop Med Public Health 35(3): 523-530.

16. Sugaroon S, Wiwanitkit V (2003) Gnathostoma infective stage larvae in swamp eels (Fluta alba) at a metropolitan market in Bangkok, Thailand. Ann Clin Lab Sci 33(1): 94-96.

17. Saksirisampant W, Thanomsub BW (2012) Positivity and intensity of Gnathostoma spinigerum infective larvae in farmed and wild-caught swamp eels in Thailand. Korean J Parasitol 50(2): 113-118.

18. Cole RA, Choudhury A, Nico LG, Griffin KM (2014) Gnathostoma spinigerum in live Asian swamp eels (Monopterus spp.) from food markets and wild populations, United States. Emerg Infect Dis 20(4): 634-642.

19. Meronek TG, Bouchard PM, Buckner ER, Burri TM, Demmerly KK, et al. (1996) A review of fish control projects. North American Journal of Fisheries Management 16(1): 63-74.

20. Cailteux RL, De Mong L, Finlayson BJ, Horton W, McClay W, et al. (2001) Rotenone in fisheries: are the rewards worth the risks. American Fisheries Society.

21. Lazur A, Early S, Jacobs JM (2006) Acute toxicity of 5\% rotenone to northern snakeheads. North American Journal of Fisheries Management 26(3): 628-630.

22. Hii YS, Lee MY, Chuah TS (2007) Acute toxicity of organochlorine insecticide endosulfan and its effect on behaviour and some hematological parameters of Asian swamp eel (Monopterus albus, Zuiew). Pesticide Biochemistry and Physiology 89(1): 46-53.

23. Hubbs C (1963) An evaluation of the use of rotenone as a means of "improving" sports fishing in the Concho River, Texas. Copeia 1963(1): 199-203.

24. Hampson BL (1976) Ammonia concentration in relation to ammonia toxicity during a rainbow trout rearing experiment in a closed freshwater-seawater system. Aquaculture 9: 61-70.

25. Burrows RE (1964) Effects of accumulated excretory products on hatchery-reared salmonids. Bureau of Sport Fisheries and Wildlife.

26. Alderson R (1979) The effect of ammonia on the growth of juvenile Dover sole, Solea solea (L.) and turbot, Scophthalmus maximus (L.). Aquaculture 17(4): 291-309.

27. Alabaster JS, Lloyd R (1980) Water Quality Criteria for Freshwater Fish. Butterwortbs, London, p. 297.

28. Sadler K (1981) The toxicity of ammonia to the European eel (Anguilla anguilla L.). Aquaculture 26(1-2): 173-181.

Your next submission with Juniper Publishers
will reach you the below assets
- Quality Editorial service
- Swift Peer Review
- Reprints availability
- E-prints Service
- Manuscript Podcast for convenient understanding
- Global attainment for your research
- Manuscript accessibility in different formats
( Pdf, E-pub, Full Text, Audio)
- Unceasing customer service
Track the below URL for one-step submission
https://juniperpublishers.com/online-submission.php

